\title{
RESPONSABILIDADE CIVIL DO ESTADO POR DANOS \\ DECORRENTES DO EXERCÍCIO DA FUNÇÃO \\ JURISDICIONAL: REGIME JURÍDICO-SUBSTANTIVO \\ E JURÍDICO PROCESSUAL
}

\begin{abstract}
Francisco Manuel lucas Ferreira de Almeida*
\end{abstract}
\author{
Acórdão do Tribunal da Relação de Coimbra \\ de 13 de novembro de $2019^{* *}$
}

\begin{abstract}
SUMÁRIO: I - O regime geral aplicável à responsabilidade civil por danos decorrentes do exercício da função jurisdicional corresponde ao regime da responsabilidade por factos ilícitos cometidos no exercício da função administrativa, com as ressalvas que decorrem do regime próprio do erro judiciário e com a restrição que resulta do facto de não se admitir que os magistrados respondam diretamente pelos ilícitos que cometam com dolo ou culpa grave.
\end{abstract}

II - Para o reconhecimento de uma obrigação de indemnizar, por parte do Estado, por facto do exercício da função jurisdicional, é necessária a existência de um erro judiciário, o qual implicará que haja a certeza de que um juiz normalmente preparado e cuidadoso não teria julgado pela forma a que se tiver chegado, sendo esta inadmissível e fora dos cânones minimamente aceitáveis, quer se esteja perante erro de direito ou de facto.

III- Essa certeza, enquanto requisito da ilicitude da responsabilidade em causa, tem de advir da prévia revogação da decisão danosa pela jurisdição competente, comportando-se, pois, esta revogação, como um pré-requisito da responsabilidade civil pelo exercício da função jurisdicional.

IV - Não se trata, no entanto, de uma qualquer revogação de uma decisão judicial, mas de uma revogação que implique, pelo seu conteúdo, o reconhecimento judicial do erro, com as caraterísticas de manifesto, quando de direito, ou de grosseiro, quando de facto.

$\mathrm{V}$ - A jurisprudência do Tribunal de Justiça da União Europeia entendeu dever ter-se por definitivamente afastada a exigência da prévia revogação da decisão danosa quando esteja em causa a apreciação da responsabilidade civil do Estado por ato da função jurisdicional em função da violação do direito comunitário por um órgão jurisdicional nacional que decida em última instância.

VI - Por isso, apenas quando o erro judiciário que origina o dever de indemnizar proceda do órgão jurisdicional que decida em última instância e

* Juiz-conselheiro Jubilado do Supremo Tribunal de Justiça. Professor Convidado da Faculdade de Direito da Universidade Lusófona (Lisboa).

** Proc. 2519/18.8T8LRA.C1, in www.dgsi.pt/Relatora: Des. ${ }^{a}$ MARIA TERESA ALBUQUERQUE. 
se reporte à devida interpretação ou aplicação do direito comunitário pode e deve ser dispensada a prévia revogação da decisão que alegadamente contém aquele erro.

\section{Comentário}

ReSUmo: o acórdão pronunciou-se sobre o tema da responsabilidade civil do Estado por danos decorrentes do exercício da função jurisdicional, com base em errojudiciário. Concluiu o aresto que a ilicitude tem de advir da prévia revogação da decisão danosa pela jurisdição competente, como pré-requisito dessa responsabilização. Revogação essa que implique o reconhecimento judicial do erro, com as caraterísticas de manifesto, quando de direito, ou de grosseiro, quando de facto. O comentário assenta no facto de o novo regime legal, entrado em vigor em 1 de janeiro de 2020, ter vindo acabar com a distinção entre decisões (supostamente) violadoras do direito europeu e decisões (alegadamente) violadoras do direito interno, ao tornar passiveis de recurso de revisão quaisquer decisöes transitadas em julgado com base em (reconhecido) erro judiciário.

Palavras-Chave: Ato Jurisdicional; Erro Grosseiro; Responsabilidade do Estado; Decisão Definitiva; Prévia Revogação; Recurso de Revisão.

ABSTRACT: the court ruling addresses the matter of the State's liability for damages arisen through the exercise of a judicial function, based on judiciary error. The ruling concluded that, as pre-requisite for said liability, unlawfulness must arise from the previous revocation of the detrimental decision by the competent jurisdiction. This revocation entails the judicial recognition of error with its characteristics in manifest when it is of law, or but grossly when it is of fact. The commentary grounds itself on the fact that the new legal regime (came into force January 1st 2020) did away with the distinction between decisions (purportedly) in breach of European Law and decision (allegedly) in breach of National Law, by making appealable for review any decision made final on the basis of (recognized) judiciary error.

KEYwORDS: Jurisdictional Act; Gross Error; State Liability; Final Decision; Previous Revocation; Review Appeal. 
1. O acórdão sob análise, supra-sumariado, seguiu na peugada da doutrina e jurisprudência ao tempo consolidadas, não tendo, porém, e naturalmente, considerado o (novel) meio processual instituído pelo art. ${ }^{\circ} 3 .^{\circ}$ da Lei ${ }^{\circ}$ $117 / 2019$, de 13 de setembro, já que este diploma só entraria em vigor em 1 de janeiro de 2020 (ex-vi do respetivo art. ${ }^{\circ} 15 .^{\circ}$ ).

Daí que, sem embargo da correção do sentido decisório nele adotado (atento o princípio tempus regit actum), a doutrina nele perfilhada haja que ser "atualizada” à luz da sobredita inovação legislativa. $\mathrm{O}$ aresto suscita, todavia, diversas questões que se prendem com o regime jurídico-substantivo e jurídico-processual vigentes e que a seguir abordaremos ex-professo.

A conclusão III do respetivo sumário encontrava-se, designadamente, em consonância com a doutrina do acórdão do Tribunal Constitucional (TC) n. ${ }^{\circ} 363 / 2015$, de 9 de julho de $2015^{1}$, que decidiu não «julgar inconstitucional a norma do art. ${ }^{\circ} 13 .^{\circ}$, n. $^{\circ} 2$, do Regime da Responsabilidade Civil Extracontratual do Estado e demais Entidades Públicas, aprovado pela Lei n. ${ }^{\circ}$ 67/2007, de 31 de dezembro (RJRCEEP), segundo a qual o pedido de indemnização fundado em responsabilidade por erro judiciário deve ser fundado na prévia revogação da decisão danosa pela jurisdição competente».

$\mathrm{Na}$ respetiva economia, esse acórdão do TC coonestou a (correta) interpretação normativa feita pelas instâncias comuns, ao rejeitar que a norma em apreço violasse o disposto nos art. ${ }^{\circ}$ s $20{ }^{\circ}$, n. ${ }^{\circ}$ s 1,4 e 5 , da Constituição da República Portuguesa (CRP), bem como, o art. $^{\circ} 6 .^{\circ}$, n. ${ }^{\circ} 1$, da Convenção Europeia dos Direitos do Homem $(\mathrm{CEDH})$, sendo que a questão da constitucionalidade foi equacionada à luz do disposto no art. $^{\circ} 18 .^{\circ}$, n. ${ }^{\circ} 2$, da CRP, em termos de se saber se tal exigência constituiria ou não uma restrição autorizada do direito consagrado no art. $^{\circ} 22 .^{\circ}$ da Lei Fundamental (LF). No fundo, o que o TC veio considerar foi que tal restrição seria «constitucionalmente justificada pela necessidade de defender a hierarquia dos tribunais consagrada no art. $^{\circ} 210 .^{\circ}$ da CRP. A sua supressão levaria à subversão dessa hierarquia, "na medida em que permitiria que (por exemplo) um tribunal de comarca julgasse de mérito uma decisão do Supremo Tribunal de Justiça, o que constituiria uma aberração" (sic).

1 In DR, n. ${ }^{\circ}$ 186/2015, Série II, de 23 de setembro de 2015, pp. 27422-27428. 
Brandia-se, até então, com a força e autoridade do caso julgado, isto é, com a definitividade/vinculatividade de uma decisão já transitada, qua tale inviabilizadora da possibilidade de outro tribunal vir, ex-post, apreciar e aferir da licitude ou ilicitude dessa decisão, ainda que sem finalidade revogatória específica. Isto sendo sabido que a exigência da prévia revogação poderia, na ausência de um meio impugnatório próprio, redundar na impossibilidade do exercício ao direito de reparação por erro judiciário.

Deparar-se-ia então um conflito de direitos: por um lado, a força vinculativa do caso julgado e, por outro, o direito à indemnização por parte do lesado com a decisão transitada em julgado. Ou seja, o direito (constitucional) a ser indemnizado, poderia estar condicionado na sua exercitação, quiçá mesmo prejudicado, por razões de ordem (meramente) processual. Mas, conforme bem reconheceu o TC, a CRP não confere um direito absoluto à indemnização, ficando salva ao legislador ordinário a possibilidade de «densificar os pressupostos da obrigação de indemnizar e o regime de responsabilidade, ainda que não possa restringir arbitrária ou desproporcionadamente o direito fundamental à reparação dos danos plasmado no art. $^{\circ} 22 .^{\circ} \mathrm{da}$ CRP, sendo que o problema poderia surgir, tanto na definição do regime substantivo da responsabilidade, como na estruturação da ação de responsabilidade» (sic). De resto, se se considerasse inconstitucional a norma do n..$^{\circ} 2$ do art. $.^{\circ} 13 . .^{\circ}$, tal significaria, em boa parte, pôr em crise, ainda que por via ínvia, a autoridade do próprio caso jugado.

Ficou, assim, encerrada, com o citado aresto do TC a (até então) instalada e ainda subsistente querela doutrinal e jurisprudencial acerca da natureza e da conformidade constitucional da exigência/condição (imposta pelo legislador ordinário) de revogação prévia da decisão danosa para que o lesado pudesse ser ressarcido na plenitude que o art. ${ }^{\circ} 22 .^{\circ}$ da CRP primariamente lhe conferia. Tudo sem embargo de o TC ter vindo a reconhecer um direito geral à reparação ou compensação dos danos provenientes de ações e omissões fundado no princípio estruturante do Estado de direito democrático acolhido no art. $^{\circ} 2 .^{\circ}$ da CRP 2 . Este «direito geral» imporia, desde logo, que o legislador

2 Cfr., os acórdãos do TC n. ${ }^{\circ}$ S 385/2005 e 444/2008, in www.tribunalconstitucional.pt/tc/ acordaos. Cfr. ainda, GOMES CANOTILHO/VITAL MOREIRA, Constituição da República Portuguesa Anotada, vol. I, 4. ${ }^{\text {e }}$ e., Coimbra Editora, Coimbra, 2007, p. 432; JORGE MIRANDA/ RUI MEDEIROS, Constituição Portuguesa Anotada, tomo I, 2. ${ }^{a}$ ed., Coimbra Editora, 2010, pp. 476 - 


\section{RESPONSABILIDADE CIVIL DO ESTADO...}

assegurasse a respetiva concretização, tal como considerado no acórdão do TC n. ${ }^{\circ} 444 / 200$.

$\mathrm{E}$, na realidade, no que respeita ao direito à indemnização baseada em responsabilidade direta do Estado e demais entidades públicas, o art. ${ }^{\circ} 22 .^{\circ} \mathrm{da}$ CRP não estabelece os concretos mecanismos processuais da sua exercitação, deixando essa tarefa para o legislador ordinário; ponto sendo que o legislador, ao fazê-lo, não criasse «entraves ou dificuldades dificilmente superáveis, nem encurtasse arbitrariamente o quantum indemnizatório $\gg$. Ao legislador infra-constitucional caberia, pois, «densificar os pressupostos da obrigação de indemnizar e o regime da responsabilidade, designadamente delimitar o conceito de ilicitude relevante e esclarecer em que medida uma ideia de culpa constitui pressuposto da responsabilidade» (igualmente sic).

Como o próprio TC reconheceu no acórdão do TC n. ${ }^{\circ}$ 683/2006, a efetivação da responsabilidade civil extracontratual do Estado, expressamente reconhecida no art. ${ }^{\circ} 22 .^{\circ} \mathrm{da} C \mathrm{CR}$, implicaria «um reexercício da função jurisdicional relativamente à mesma questão de direito ou de facto: uma primeira decisão judicial seria considerada errada por um ato jurisdicional subsequente» (sic); assim, constituiria sempre condição necessária da procedência de uma eventual ação de indemnização a verificação de que a pretensa decisão danosa incorrera num erro de direito - v. g., de uma norma inconstitucional -, verificação essa que obrigaria a um reexame da questão de direito — ou seja, a um segundo juizo sobre a constitucionalidade da norma aplicada pela primeira decisão. "Reexercício" que poderia ocorrer «no âmbito de um recurso ordinário interposto da primeira decisão (no fundo, a situação prevista no art. ${ }^{\circ} 13 .^{\circ}$, n. ${ }^{\circ}$, do RJRCEEP) ou fora dele, por ausência de meio processual próprio e específico».

A doutrina sufragada pelo TC desde o acórdão n. ${ }^{\circ}$ 90/84 já destacara o ilogismo institucional — "no fundo, a subversão do princípio da divisão dos poderes, enquanto também aplicável à organização da ordem judiciária" - que representaria uma solução que prescindisse de um requisito como o estatuído no art. ${ }^{\circ} 13 .^{\circ}$, n. $^{\circ} 2$, do RJRCEEP: a lógica do sistema rejeitava a ideia de que uma decisão judicial transitada em julgado pudesse vir a ser

477; e ALVES CORREIA, $A$ indemnização pelo sacrifício: contributo para o esclarecimento do seu sentido e alcance, in RLJ, Ano 140 (2011), n. ${ }^{\circ} 3966$, p. 143-146. 


\section{FRANCISCO MANUEL LUCAS FERREIRA DE ALMEIDA}

posteriormente «desautorizada » - isto é, em concreto afastada ou desconsiderada - , mesmo que só incidentalmente e para efeitos de verificação de erro de julgamento relevante em sede de responsabilidade civil por «facto» da função jurisdicional - por outro tribunal "porventura até de diferente espécie ou pertencente a uma diversa ordem de jurisdição, ou inclusivamente da mesma espécie, mas de grau inferior", "mesmo que para os efeitos limitados de reconhecimento de um erro judiciário, por outro tribunal — porventura até de diferente espécie ou pertencente a uma ordem jurisdicional distinta" (sic).

Seria, pois, na própria natureza da função jurisdicional e no modo como o respetivo exercicio se encontrava estruturado - o sistema de recursos e a hierarquia dos tribunais plasmados na LOSJ e no CPC - que poderia vir a ser encontrada justificação para uma limitação como a estatuída no $n .^{\circ} 2$ do art. ${ }^{\circ}$ $13 .^{\circ}$ do RJRCEEP.

No que respeita à panóplia de ilícitos potencialmente geradores de indemnização, haveria então, como hoje, que distinguir (como distinguiu o TC) entre os que «não são imputáveis ao funcionamento da administração da justiça em geral, dos especificamente imputáveis a um concreto erro judiciário $\gg^{3}$. Na verdade, uma coisa é a responsabilidade por atos e omissões de natureza jurídico-administrativa que ocorram no âmbito da função jurisdicional e imputáveis aos magistrados ou funcionários ou à administração judiciária globalmente considerada; outra é a responsabilidade desencadeada pelo conteúdo de uma dada (e concreta) decisão jurisdicional . $^{4}$

No fundo, o n. 2 do art. ${ }^{\circ} 13 .^{\circ}$ do RJRCEEP, instituía uma verdadeira condição (deprocedência) da ação para efetivação da responsabilidade por erro

3 Sobre a distinção entre erro judiciário e factos imputáveis à «administração judiciária», cfr. o art. $^{\circ} 4 .^{\circ}$, n..$^{\circ}$ 1, alínea g), e 3. ${ }^{\circ}$, alínea a), do Estatuto dos Tribunais Administrativos e Fiscais (ETAF), aprovado pela Lei n. ${ }^{\circ} 13 / 2002$, de 19 de fevereiro, com as últimas alterações introduzidas pela Lei n. $114 / 2019$, de 12 de setembro, e os art. ${ }^{\circ}$ s $12 .^{\circ}$ e $13 .^{\circ}$ do RJRCEEP.

4 Acerca deste tema, cfr., por todos: CARDOSO DA COSTA, Sobre o novo regime da responsabilidade do Estado por atos da função judicial, in RLJ, Ano 138. . (2009), n. ${ }^{\circ} 3954$, p. 156 e ss., pp. 160-164; CARLOS CADILHA, Regime da Responsabilidade Civil Extracontratual do Estado e

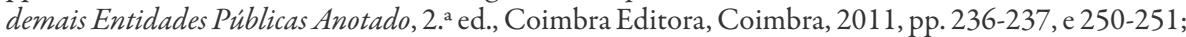
LUÍS S. FÁBRICA, in Comentário ao Regime da Responsabilidade Civil Extracontratual do Estado e demais Entidades Públicas, Universidade Católica Editora, Lisboa, 2013, pp. 323-329; MARIA JOSÉ RANGEL DE MESQUITA O Regime da Responsabilidade Civil Extracontratual do Estado e demais Entidades Públicas e o Direito da União Europeia, Almedina, Coimbra, 2009; e JONATAS MACHADO, "A responsabilidade dos Estados Membros da União Europeia por atos e omissóes do Poder Judicial', in RLJ, Ano 144..$^{\circ}(2015)$, n. $^{\circ} 3991$, p. 246 e ss.. 


\section{RESPONSABILIDADE CIVIL DO ESTADO...}

judiciário. A ausência de revogação da decisão danosa fundada num vício de julgamento qualificável como erro judiciário determinaria, só por si, a improcedência da ação de responsabilidade. Em rigor, essa norma concorreria, juntamente com a do $n .^{\circ} 1$ do mesmo preceito, para a configuração do conteúdo do direito de indemnização emergente da responsabilidade do Estado por erro judiciário do Estado $\gg^{5}$. Com efeito, essa norma traduz a consagração legislativa do direito à indemnização por erro judiciário civil na parte respeitante à determinação de quem é o juiz competente para realizar a apreciação da decisão judicial danosa.

Em sentido idêntico e acerca do aresto supra-sumariado se havia já pronunciado o acórdão da Relação de Coimbra (RC) de 3-11-20156. Considerou, inter alia, este aresto que o RJRCEEP «é justificado pela especificidade da função jurisdicional, em relação às demais incumbências do Estado, traduzida na respetiva natureza e na independência dos juizes, mas também na forma como o respetivo exercício está estruturado, em que se realça o sistema de recursos»; «tais natureza e estrutura, embora não possam vedar a possibilidade de responsabilização efetiva, tanto do Estado como dos juizes -estes, por via de ação de regresso - , exigem a conceção do aludido regime como estando balizado pela necessidade de contenção do direito à indemnização e da imposição de limites» (sic). Nessa senda, excluída estaria a «responsabilidade do Estado por atos de simples interpretação do direito e de valoração dos factos, porque inseridos na essência da especificidade da função jurisdicional, que, por isso, deve ser salvaguardada $\gg($ sic $)$.

$\ll \mathrm{O}$ reconhecimento do fundamento do direito à reparação da responsabilidade do Estado pelos danos causados por erro judiciário - ou seja, de que a decisão de $1{ }^{a}$ instância seria totalmente estranha à situação jurídica em apreço, fruto de erro de julgamento, manifesto e indesculpável - teria de ser patenteado pelos termos da própria decisão revogatória proferida no processo judicial em que, alegadamente, fora cometido o erro. Essa opção legislativa, apesar do seu caráter restritivo, compatibilizaria adequada e proporcionadamente o instituto da responsabilidade civil com a garantia

5 Cfr. VIEIRA DE ANDRADE, Os Direitos Fundamentais na Constituição Portuguesa de 1976, cit., p. 213.

6 Proc. 136/14.0TBNZR.C1, in www.dgsi.pt/Relator: Des. ALEXANDRE REIS. 
da segurança e da certeza jurídica do caso julgado e, por isso, não cerciaria arbitrariamente o principio da responsabilidade do Estado nem o principio da igualdade» (sic).

«A mera revogação da decisão pela via do recurso, pelo tribunal hierarquicamente superior em sobreposição ao tribunal a quo, significava, apenas, terem sido apresentadas duas diferentes apreciaçôes fáctico-juridicas, e/ou duas diferentes soluções jurídicas para uma mesma concreta situação, ambas igualmente legítimas - ainda que só uma tenha prevalecido - não, necessariamente, que a decisão recorrida padecesse de erro, muito menos, de erro manifesto».

Quanto ao "meio de que o lesado disporia para (pressuposta a constitucionalidade da exigência da revogação prévia da decisão ilícita), obter esta revogação", à míngua de qualquer meio específico legalmente previsto, propugnava-se a admissibilidade de uma ação comum, «dado que nenhum direito ou interesse juridicamente tutelável poderia ficar sem possibilidade de tutela jurisdicional» (ex-vi do art. ${ }^{\circ} 2 .^{\circ}$ do CPC $)$. Solução que, todavia, iria ao arrepio do que (aparentemente) teria pretendido o legislador evitar com a exigência da revogação prévia: a apreciação da licitude de uma decisão dos tribunais superiores por um tribunal de primeira instância. O que não seria aceitável - nem constitucional - era exigir-se a revogação prévia da decisão e não se facultar, numa situação em que o recurso ordinário fosse inadmissivel, nenhum meio processual especificamente vocacionado para obter essa revogação.

Idêntico deficit instrumental se colocaria na hipótese de ser dispensada a exigência da revogação prévia e de, portanto, se aceitar uma ação de indemnização sem essa prévia revogação: também nesta hipótese, haveria que definir qual o meio processual para fazer valer essa indemnização e qual o órgão competente para apreciar a ilicitude da decisão e definir as respetivas consequências, sendo que, «para além da indemnização ao lesado, se colocaria sempre, necessariamente, o problema da subsistência da decisão no ordenamento jurídico ${ }^{7}$.

7 Cfr. M. TEIXEIRA DE SOUSA, em comentário a este aresto, in blog do IPPC de 01-12-2015, Jurisprudência (240) 
2. O acórdão, ora sob apreciação, partiu do princípio de que o erro judiciário atendível para efeitos indemnizatórios implicaria «que houvesse a certeza de que um juiz normalmente preparado e cuidadoso não teria julgado pela forma como o foi, sendo esta inadmissível e fora dos cânones minimamente aceitáveis, quer se estivesse perante erro de direito ou de facto» (sic); «certeza essa que, enquanto requisito da ilicitude da responsabilidade em causa, teria de advir da prévia revogação da decisão danosa pela jurisdição competente, comportando-se, pois, esta revogação, como um pré-requisito da responsabilidade civil pelo exercício da função jurisdicional» (sic).

E mais que: «não se trataria, no entanto, de uma qualquer revogação de uma decisão judicial, mas de uma revogação que implicasse, pelo seu conteúdo, o reconhecimento judicial do erro, com as caraterísticas de manifesto, quando de direito, ou de grosseiro, quando de facto» (sic).

Para a superação do problema legal em equação, e para a hipótese de se manter a necessidade da revogação prévia da decisão (o que implicaria construir um regime que permitisse tornear a jurisprudência do TJ de 9/9/2015 (C-160/14)), importaria estabelecer qual o meio processual, além do recurso ordinário, concedido aos interessados para tal revogação e qual o órgão com competência para essa revogação $\gg(\text { sic })^{8}$.

Solução que o legislador — agindo na lógica do sistema —encontrou com a instituição, pelo art. ${ }^{\circ} 3 .^{\circ}$ da Lei n. $.^{\circ} 117 / 2019$, de 13 de setembro, do (novo) fundamento da al. h) do art. ${ }^{\circ} 6966^{\circ}$, completado pela estatuição dos noveis art. ${ }^{\circ} \mathrm{s} 696$. $^{\circ}$ A, 701. ${ }^{\circ}$ e 701. ${ }^{\circ}-A$, todos do CPC, como, mais adiante, melhor explanaremos.

3. Só, pois, com a entrada em vigor da Lei n. ${ }^{\circ} 67 / 2007$, de 31 de dezembro (RJRCEEP) e uma vez reunidos os pressupostos dos respetivos art. ${ }^{\circ} \mathrm{S} 12 .^{\circ} \mathrm{e}$ 13. ${ }^{\circ}$, a responsabilização do Estado pela prática de atos jurisdicionais ilícitos de natureza civilistica ganhou foros de consagração. A jurisprudência coeva

8 Cfr. M. TEIXEIRA DE SOUSA, in blog do IPPC, de 20-4-2020, Jurisprudência 2019 (221), em comentário ao acórdão da RC de 13-11-2019, Proc. 2519/18.8T8LRA.C1. 
do $\mathrm{TC}^{9}$ e do STJ era concordante no sentido de o Dec.-Lei n. 48 051, de 21 de novembro de 1967, só ser aplicável à responsabilidade do Estado e as demais pessoas coletivas públicas por atos de gestão pública que não também aos atos de carácter jurisdicional. Isto sem embargo de, no que toca especificamente às vertentes penal e processual, já antes o art. ${ }^{\circ} 225^{\circ} \mathrm{do}$ $\mathrm{CPP} / 87$ haver provido acerca do direito ao arbitramento de indemnização por quem «tiver sofrido detenção sofrido detenção ou prisão preventiva manifestamente ilegal» (n. $\left.{ }^{\circ} 1\right)$ ou que, não sendo ilegal, venha a revelar-se injustificada por erro grosseiro na apreciação dos pressupostos de facto de que dependa $»\left(n .^{\circ} 2\right)$, ressalvando-se o caso de «o preso ter concorrido, por dolo ou negligência, para aquele erro ${ }^{10}$.

No já provecto acórdão do STJ de 11-12-1998 ${ }^{11}$ considerou-se, inter alia (na sugestiva sinonímia de MANUEL DE ANDRADE), que, «para os fins e efeitos do art. ${ }^{\circ} 225 .^{\circ}$ do CPP, erro grosseiro «será um qualquer erro indesculpável no sentido de escandaloso, crasso ou supino, o chamado "error intolerabilis”, aquele em que não teria caído uma pessoa dotada de normal inteligência e circunspecção ${ }^{12}$. E, outrossim, que: «o erro grosseiro poderá não existir aquando do ato inicial do decretamento da medida de prisão preventiva, mas cometer-se no decurso ou a partir de certo momento do período em que tal situação se mantenha. Mas, caso tal erro se não venha a apurar, mesmo assim, a simples subsistência, por um longo período, da privação da liberdade que venha a revelar-se "ab initio" injustificada, assume, em princípio, um caráter de gravidade, penosidade e anormalidade merecedor da tutela do direito para fins indemnizatórios» (sic).

$\mathrm{O}$ CPP/87 interpreta corretamente o sentido da norma constitucional (do art. ${ }^{\circ} 22 .^{\circ}$ da CRP), ao estender o dever de indemnização aos casos de prisão preventiva que, não sendo ilegais, se revelarem injustificados por erro grosseiro

9 Uma vez que estes não podem considerar-se de "gestão" - cfr., $v$. g., o acórdão no 90/84, de 30 de julho, Processo n. ${ }^{\circ} 82 / 83$.

10 Cfr., neste sentido, SALVADOR DA COSTA, em intervenção no Colóquio subordinado ao tema "Carreira dos Juizes - Perspectivas de Futuro", organizado pelo Fórum Permanente da Justiça Independente, no dia 23 de janeiro de 2009 e CARDOSO DA COSTA, in RLJ, Ano 138. " "Sobre o novo regime da responsabilidade do Estado por actos da função jurisdicional', pp. 156 a 168.

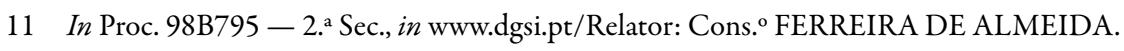

12 In "Direito Civil - Teoria Geral", vol. II, pp. 234 e 239. 


\section{RESPONSABILIDADE CIVIL DO ESTADO...}

(grober Fehler) na apreciação dos pressupostos de facto de que dependia e se da privação da liberdade resultaram prejuizos anómalos e de particular gravida$d e$. Destarte, no que especificamente tange às situações de decretamento ou manutenção de uma situação de prisão preventiva em infração a preceitos de natureza constitucional ou legal, encontram, pois, elas hoje a sua regulamentação própria e específica no capítulo $\mathrm{V}$ do título II do CPP, cujos preceitos, embora inseridos no âmbito de um diploma de caráter essencialmente adjetivo, assumem natureza eminentemente substantiva.

Conforme o mesmo aresto do STJ, «no n. ${ }^{\circ} 1$ do art. $225 .^{\circ}$ prevêem-se, não só as prisões ou detenções preventivas manifestamente ilegais, v.g., as levadas a cabo por quaisquer entidades administrativas ou policiais, como ainda por magistrados judiciais, agindo estes desprovidos da necessária competência legal ou fora do exercício do seu múnus ou sem utilização do processo devido, ou mesmo, atuando investidos da autoridade própria do cargo, se hajam determinado à margem dos princípios deontológicos e estatutários que regem o exercício da função judicial ou impulsionados por motivações com relevância criminal, v.g., por peita, suborno, corrupção, concussão, abuso do poder ou prevaricação» (sic). Já, no n. ${ }^{\circ} 2$, se contemplam «as situações em que a prisão possua cobertura legal, quer pela qualidade e autoridade do órgão ou agente que a haja decretado, quer pelos pressupostos abstratamente vertidos na lei para tal decretamento. E para que, em tais hipóteses, ocorra o dever de indemnizar, coloca a lei as seguintes condições de verificação cumulativa necessária: - se a prisão preventiva vier a revelar-se injustificada por erro grosseiro na apreciação dos pressupostos de facto de que dependia; - se a privação da liberdade tiver causado ao detido ou preso prejuizos anómalos e de particular gravidade. Isto tudo salvo se o preso ou detido houver concorrido, por dolo ou negligência, para aquele erro» — conf. parte final desse inciso normativo» (transcrição do aresto cit.).

Neste âmbito, a lei processual penal só leva em conta, para fundamentar a responsabilidade do Estado e consequente direito à indemnização, o "erro grosseiro", isto é, aquele em que um agente minimamente cuidadoso não incorreria, e a "ilegalidade manifesta" (no sentido de flagrante, evidente, ostensiva ou notória), isto é, aquela em que se torna evidente (para qualquer homem médio) mesmo numa apreciação superficial" 
(sic). Não, pois, se «a apreciação dos pressupostos de facto de que depende a prisão preventiva for da competência do juiz do processo e se apresentem como inquestionáveis, quer a competência funcional e legal do magistrado decisor, quer o quadro normativo-legal em que se moveu» (sic).

De realçar que a lei se refere a pressupostos de facto e não a pressupostos de direito; torna-se, por tal, evidente que pretendeu afastar da respetiva previsão os casos em que haja sido cometido qualquer erro acerca da lei aplicável ou da qualificação jurídica dos factos em presença, ou seja, erro de direito em qualquer das suas modalidades de erro na aplicação, erro na interpretação ou erro na qualificação. E isto sem dúvida com o objetivo de preservar a independência dos juizes na administração da justiça, os quais se encontram, no exercício da sua competência funcional, apenas limitados pelo dever de obediência à Constituição e à Lei e pelo respeito pelos juizos de valor legais, não podendo ser penalizados pelos juízos técnicos emitidos nas respetivas decisões, ainda que estas possam, em via de recurso, ser alteradas por tribunais de hierarquia superior - cfr. os art. ${ }^{\circ} \mathrm{s} 202 .^{\circ}$ a $204 .^{\circ}$ da CRP e $4 .^{\circ}$ e $5 .^{\circ}$ do Estatuto dos Magistrados Judiciais (CMJ) 85 aprovado pela Lei n. ${ }^{\circ} 21 / 85$ de 30 de julho. Liberdade de aplicação do direito que, de resto, a lei processual civil especialmente contempla no $n .^{\circ} 3$ do art. ${ }^{\circ} 5 .^{\circ}$ do atual CPC.

Conforme se observou no supra-citado acórdão do TC n ${ }^{\circ}$ 90/84, «o facto de uma decisão do juiz de $1^{a}$ instância acabar por ser revogada pelo tribunal superior nem por isso lhe "faz perder o caráter de ato judicial lícito, pois que proferido no uso de uma competência legal" "e com respeito pelos princípios deontológicos que regem o exercício da função de julgar” (sic). E mais que: «os recursos judiciais visam apenas o controlo material do conteúdo das decisões e não o controlo funcional da conduta dos juízes"; "visam permitir que a questão contenciosa seja reapreciada por outro tribunal, suposto melhor qualificado para o seu julgamento mas sem que tal reapreciação afete a legitimidade funcional" da decisão do tribunal inferior» $(s i c)$.

Não há, assim, incompatibilidade, mas sim complementaridade, entre a previsão genérica do art. ${ }^{\circ} 22 .^{\circ}$ e a previsão especifica do art. ${ }^{\circ} 27 .^{\circ}, \mathrm{n} .^{\circ} 5$, ambos da CRP, já que este último inciso constitucional representa um alargamento (um “majus") da responsabilidade civil do Estado já consagrada naquele anterior normativo. 
A primeira parte do n. ${ }^{\circ} 1$ do art. $^{\circ} 13 .^{\circ}$ da Lei n. ${ }^{\circ} 67 / 2007$, de 31 de dezembro, reporta-se ao regime consagrado nos art. ${ }^{\circ} \mathrm{s} 225 .^{\circ}, 226 .^{\circ}, 461 .^{\circ}$ e $462 .^{\circ} \mathrm{do}$ CPP. A expressão «sem prejuizo do regime especial», contida no proémio desse.$^{\circ} 1$, significa que o regime previsto no CPP (lex specialis) prevalece sobre o esquema mais recente da segunda parte do preceito (lex generalis). Nesta sede, "a relação entre os dois regimes legais não é de cumulação ou de alternatividade".

De salientar, a talho de foice, que a alínea a) do $n .^{\circ} 1$ do art. ${ }^{\circ} 225 .^{\circ}$ do CPP não remete em bloco para o regime do habeas corpus, mas apenas para os preceitos que enunciam os fundamentos da ilegalidade da prisão (art. ${ }^{\circ} \mathrm{s}$ $220 .^{\circ}$, n. $^{\circ} 1$, e $222 .^{\circ},{ }^{\circ}{ }^{\circ}$, do CPP); o que significa que a decisão judicial que tenha aplicado a medida de prisão preventiva quando a lei a não permite (art. ${ }^{\circ} 222 .^{\circ}$, n. $^{\circ} 2$, alínea b), do CPP), pode ser revogada pela via do recurso ou mediante a providência do habeas corpus. A redação dessa alínea, introduzida pela Lei n. ${ }^{0} 48 / 2007$, a e eliminar a expressão «manifesta», balizou também o conceito objetivo de prisão ilegal, concatenando-o com os fundamentos do habeas corpus.

De realçar, outrossim, que a decisão judicial declarativa da ilegalidade da prisão surte força e autoridade do caso julgado na ação fundada em responsabilidade do Estado por essa privação da liberdade. «Se o legislador previu a exclusão do dever de indemnizar caso o arguido haja concorrido, por dolo ou negligência, para a privação da sua liberdade, nos casos das alíneas b) e c) do n..$^{\circ} 1$ do art. $^{\circ} 225 .^{\circ}$ do CPP, quis deixar «incólume» a alínea a), por se reportar ao caso mais gravoso - à prisão ilegal. Seria ignorar ou subverter a ratio legis, aplicar, neste ponto, o regime do art. ${ }^{\circ} 4 .^{\circ}$ da Lei ${ }^{\circ}{ }^{\circ} 67 / 2007$ ou o do art. $^{\circ} 570 .^{\circ}$ do CC» $(\text { sic })^{13}$.

\section{Mas o que deve entender-se por decisões jurisdicionais?}

As decisões jurisdicionais a levar em conta, quanto esta temática jurídico-processual, são, não apenas as decisões jurisdicionais finais (maxime, a sentença

13 Cfr. o acórdão da RL de 21-5-2020, Proc. 17751/18.6T8LSB.L1-2, in www.dgsi.pt/Relatora: Des. ${ }^{a}$ GABRIELA CUNHA RODRIGUES. 
ou acórdão, que ponham termo ou dirimam um dado litígio ou conflito de interesses), como qualquer outra decisão ou medida definidoras de uma concreta situação jurídica jurídico-processual ou jurídico substantiva; daí que o conceito de sentença não deva ser tomado no seu sentido técnico-processual, sendo que, para além das decisões definitivas (de forma ou de mérito), determinantes da extinção total ou parcial da instância $(v \cdot g$., em processos cautelares e incidentais), deve englobar outras decisões e mesmo certos despachos de caráter final, interlocutório ou incidental, v.g. os que decidam a admissão de articulados supervenientes, requerimentos probatórios, a ampliação ou alteração do pedido/causa de pedir ou modificações objetivas e/ou subjetivas da instância, que possam surtir influência na decisão final).

Secundando GOMES CANOTILHO (cfr. ob. e loc. cits.), «sob pena de se paralisar o funcionamento da justiça e perturbar a independência dos juízes, impõe-se aqui um regime particularmente cauteloso, afastando, desde logo, qualquer hipótese de responsabilidade por atos de interpretação das normas de direito e pela valoração dos factos e da prova», porquanto «não se intentam acções de responsabilidade para contestar a interpretação de normas e a valoração dos factos e dos meios probatórios. Quando assim se pretende proceder, utiliza-se a via do recurso» (sic). O que significa «que quem propõe uma ação de responsabilidade civil contra o Estado por erro judiciário tem, à partida, que, em função das várias decisões jurisdicionais que hajam sido proferidas sobre a matéria do litígio, situar e definir o erro que está em causa, e fazê-lo de tal modo que o mesmo resulte configurado como «manifesto» (quando de direito) ou «grosseiro» (quando de facto)».

Importa, nesta sede, ter em consideração, como sucede genericamente em matéria de responsabilidade civil, a verificação dos pressupostos da obrigação de indemnizar plasmados no art. ${ }^{\circ} 483 .^{\circ}$ do Código Civil (CC), ou seja, não só o facto (incursão erro grosseiro), mas também a ilicitude, a culpa, o dano (sem dano não há responsabilidade civil) e o nexo de causalidade entre o facto e o dano (esse erro há-de perfilar-se como causa adequada do dano, aferida esta pela teoria da causalidade adequada na sua formulação negativa, acolhida no art. $^{\circ} 563 .^{\circ}$ do CC) $)^{14}$.

14 Cfr., no mesmo sentido, o citado acórdão do TC n. ${ }^{\circ}$ 160/95 - Proc. 562/92, de 22-03-95. Acerca da caraterização do erro judiciário, nas vertentes de direito ou de facto (manifesto ou grosseiro) - 


\section{RESPONSABILIDADE CIVIL DO ESTADO...}

No que concerne aos pressupostos da ilicitude e da culpa no exercício da função jurisdicional suscetíveis de importar responsabilidade civil do Estado, só podem dar-se como verificados (esses pressupostos) nos casos de evidente denegação da justiça, «tais como a demora na sua administração, a manifesta falta de razoabilidade da decisão, o dolo do juiz, o erro grosseiro em grave violação da lei, a afirmação ou negação de factos incontestavelmente não provados ou assentes nos autos, por culpa grave indesculpável do julgador» (cfr. mesmo autor por último citado).

Relativamente ao erro na apreciação dos pressupostos de facto, obtempera CARLOS CADILHA, acerca da qualificação do erro como grosseiro, que «esta especial qualificação do erro, quando está em causa uma decisão de facto, parece relacionar-se com o condicionalismo da formação da convicção do juiz relativamente a meios de prova que sejam de livre apreciação»; o erro quanto à matéria de facto (deve), assim, circunscrever-se «aos casos em que houve um clamoroso erro de avaliação dos meios de prova, ressalvando-se as situações em que a decisão de facto, mesmo que tenha sido alterada por um tribunal de recurso, ainda assim se enquadra dentro dos limites da contingência e da falibilidade de um juízo de convicção psicológica sobre a valoração da prova », pelo que «o erro na apreciação das provas tanto pode respeitar a um erro sobre a admissibilidade e valoração dos meios de prova, como a um erro sobre a fixação dos factos matéria da causa» (sic). Para concluir que, «devendo o erro de direito ou o erro de facto gerar inconstitucionalidade ou ilegalidade, estas são, só por si, expressão de ilicitude» (igualmente sic).

5. A responsabilidade do Estado por erro judiciário, para além da previsão genérica do direito à reparação pelos ilícitos cometidos pelos titulares dos órgãos do Estado e demais entidades públicas, abrange também os juizes e os ilícitos que estes eventualmente cometam no exercicio das respetivas funções.

cfr., v. g., os acórdãos do STJ de 23-10-2014, 24-2-2015 e de 10-5-2016, in Procs, 1668/12.0TVLSB. L1.S1 (Relatora: Cons. ${ }^{a}$ FERNANDA ISABEL PEREIRA), 2210/12.9TVLSB.L1.S1 (Relator: Cons. ${ }^{\circ}$ PINTO DE ALMEIDA) e 136/14.0TBNZR.C1.S1 (Relator: Cons. ${ }^{\circ}$ FONSECA RAMOS), respetivamente, todos in www.dgsi.pt. 
$\mathrm{O}$ apuramento da responsabilidade (extracontratual) dos magistrados cabe aos tribunais judiciais (se o erro houver sido cometido por tribunal ou juiz $\mathrm{da}$ ordem jurisdicional comum) ou aos tribunais administrativos (se o erro houver sido cometido por tribunal ou juiz da ordem administrativa e fiscal) - cfr. a al. b) do n. 3 e 4. ${ }^{\circ}$, al. a), do art. $4 .^{\circ}$ do ETAF. De notar, porém, no que particularmente se refere a essa responsabilidade, que o art. ${ }^{\circ} 14 .^{\circ} \mathrm{da}$ Lei n. ${ }^{\circ}$ 67/2007 postula que, «sem prejuízo da responsabilidade criminal em que possam incorrer (por ex., por suborno - art. ${ }^{\circ} 363^{\circ}$, denegação de

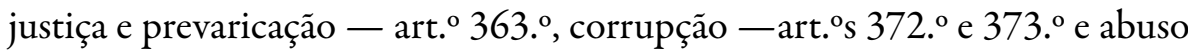
do poder - art. $^{\circ} 382 .^{\circ}$, todos esses preceitos do CP), os magistrados judiciais e do Ministério Público não podem ser diretamente responsabilizados pelos danos decorrentes dos atos que pratiquem no exercício das respetivas funções, mas apenas quando tenham agido com dolo ou culpa grave (art. ${ }^{\circ} \mathrm{s} 5 .^{\circ}$ do Estatuto dos Magistrados Judicias (EMJ) e $77 .{ }^{\circ}$ do Estatuto do Ministério Público (EMP). «Os juizes não podem ser (pessoalmente) responsabilizados pelas suas decisóes $\gg$ (julgamentos de facto ou de direito) ou pelo seu eventual conteúdo erróneo, «salvas as exceções consignadas na lei» - $\operatorname{art}^{\circ}{ }^{\circ}$ s $216 .^{\circ}$, n. ${ }^{\circ}$ 2, da CRP e $5 .^{\circ}$, n. ${ }^{\circ}$ s 1 e 2 , do EMJ $»$. «Isto como garantia das suas independência e imparcialidade, afastando qualquer veleidade de cedência ao maior voluntarismo ou combatividade de uma qualquer das partes para se eximir a uma révanche de cariz indemnizatório dirigida «ad hominem»; por outro lado, para prevenir que as suas decisões fiquem à mercê da sindicância $\mathrm{e}$ controlo por banda de outros juízes seus pares fora das vias normais de recurso. O princípio é, pois, o de que ao juiz assiste o direito ao erro (the right to be wrong ou le droit à l'erreur), restando às partes lesadas com a decisão errada ou injusta, ainda que tenha havido negligência grosseira (culpa lata), contra as mesmas desencadear os meios de reação legalmente admissíveis (reforma $\operatorname{art.}^{\circ} 616 .^{\circ}$, n. $^{\circ} 2-$ ou recurso - art. $^{\circ} 627 .^{\circ}$, n. $\left.{ }^{\circ} 1\right)^{15-16}$.

15 Cfr., acerca deste tema, F. FERREIRA DE ALMEIDA, Direito Processual Civil, vol. I, $3^{\text {a }}$ edição Almedina, 2019, pp. 404-407.

16 Cfr., quanto a este ponto, M. HENRIQUE MESQUITA, in Ab Uno Ad Omnes -75 anos da Coimbra Editora, Coimbra, 1998, pp. 1389 e respetiva nota 1, para quem «existe negligência grosseira sempre que a decisão enferme de um erro tão grave que um juiz normalmente consciencioso não o teria cometido» (sic). 
6. Antes da entrada em vigor da citada Lei n. ${ }^{\circ}$ 117/2019, perfilava-se como manifesta a incompatibilidade com o direito da União Europeia (doravante DUE) a solução consagrada no art. $^{\circ} 13 .^{\circ}, n .^{\circ} 2$, do RCEEP), em especial por força da jurisprudência Köbler ( $\mathrm{n}^{\circ}{ }^{\circ} 33$ a 36) e Traghetti ( ${ }^{\circ}{ }^{\mathrm{s}} 33$ a 40). A partir destes arestos, passou geralmente a admitir-se a responsabilidade de um Estado, membro da União, em consequência da violação do direito da União imputável ao exercício da função jurisdicional, mesmo que tal violação resultasse da decisão de um tribunal que decidisse em última instância. Consequentemente, o art. $.^{\circ} 13 .^{\circ}$, n..$^{\circ}$ 2, do RCEEP seria inaplicável à responsabilidade do Estado Português por açôes e omissóes dos seus tribunais violadoras de normas do direito da União Europeia.

Não surpreende, assim, que o acórdão ora objeto de comentário, tendo, sem dúvida, presente o quadro jurídico (legal, doutrinal e jurisprudencial ao tempo vigente), houvesse decidido que «deve ter-se por definitivamente afastada a exigência da prévia revogação da decisão danosa quando esteja em causa a apreciação da responsabilidade civil do Estado por ato da função jurisdicional em função da violação do direito comunitário por um órgão jurisdicional nacional que decida em última instância» (sic). Mas, para a hipótese de se manter a necessidade da revogação prévia da decisão (o que implicaria construir um regime que permitisse ultrapassar a jurisprudência do TJ 9/9/2015 (C-160/14)), manteve esse acórdão que cumpriria estabelecer qual o meio processual, além do recurso ordinário, concedido aos interessados para essa revogação e qual o órgão com competência para essa revogação.

No quadro do direito da União Europeia (DUE) e face à impossibilidade de os cidadãos (as partes interessadas) demandarem diretamente os EstadosMembros junto do TJUE por violação do DUE ou de forçarem o reenvio prejudicial em vista da sua correta interpretação e aplicação (cfr., respetivamente, os art. ${ }^{\circ}$ s $258 .^{\circ}, 259 .^{\circ}$ e $267 .^{\circ}$, todos do Tratado sobre o Funcionamento da União Europeia - TFUE), a tutela secundária correspondente à responsabilidade do Estado-Membro fundada em erro judiciário relativo ao DUE era entendida (ao tempo) como um relevante fator de tutela jurisdicional dos 
direitos dos cidadãos conferidos pelo DUE e de garantia da respetiva primazia face ao direito de cada um dos Estados-Membros.

Como a jurisprudência do TJUE evidenciava (cfr., v.g., o supra-citado Acórdão Köbler), os problemas não se situavam no plano técnico-processual do respeito do caso julgado (vide, em especial, o respetivo n. ${ }^{\circ} 39$ ): «um processo destinado a responsabilizar o Estado não tem o mesmo objeto e não envolve necessariamente a mesma identidade de partes que o processo que deu origem à decisão danosa e que, entretanto, haja transitado em julgado »; o objeto da ação de indemnização contra o Estado traduzir-se-ia na condenação deste no ressarcimento do dano sofrido (tutela secundária), mas não a revogação ou revisão da decisão que causou o dano (tutela primária).

A propósito da responsabilidade dos Estados-Membros por erro judiciário, JÓNATAS MACHADO chegou mesmo a falar em "disfunçôes sistémicas" a propósito "das apontadas dificuldades em conciliar a sindicabilidade das decisões tendo por objeto o DUE com a estrutura hierarquizada (vertical) das ordens jurisdicionais internas; «anomalias (todavia) — no entendimento do mesmo autor — «amplamente compensadas pela necessidade de assegurar a primazia e a efetividade do DUE e da jurisprudência do TJUE, juntamente com a tutela jurisdicional efetiva dos particulares diante das decisões dos tribunais nacionais de última instância que violem direitos e interesses legalmente protegidos pelo DUE» ${ }^{17}$.

Na mesma sendo, no acórdão do TJUE de 9/9/15 (C160/14, Ferreira da Silva e Brito et al./Estado português) decidiu-se que «o direito da União e, em especial, os princípios formulados pelo TJUE em matéria de responsabilidade do Estado por danos causados aos particulares em virtude de uma violação do DUE - cometida por um órgão jurisdicional que decide em última instância - devem ser interpretados no sentido de que se opõem a uma legislação nacional que exige como condição prévia a revogação da decisão danosa proferida por esse órgão jurisdicional, quando essa revogação se encontra, na prática, excluida» (sic). Tal jurisprudência, como que veio "introduzir" no ordenamento português uma duplicidade de regimes: uma para o erro judiciário por violação do direito europeu (em que a prévia revogação da decisão não podia ser exigida); outra para o erro por violação do direito interno e do direito

17 In ibidem, p. 288; cfr. também o Acórdão Köbler, n.o s 33 a 36. 
decorrente de convenções internacionais (em que aquela revogação continuava a ser requerida). ${ }^{18}$

No que toca ao reenvio prejudicial, decidiu a Relação de Lisboa (RL), por acórdão de 20 de dezembro de $2018^{19}$, que «o reenvio prejudicial para o TJUE deve ter por objeto a interpretação ou a validade do DUE, e não das regras de direito nacional ou questões de facto suscitadas no litígio no processo principal. O TJUE não é, por exemplo, competente para sindicar a decisão de um órgão jurisdicional de um Estado-Membro, proferida em processo pendente, nos termos da qual se declarou incompetente, em razão da matéria, para conhecer do objeto da causa, por considerar que a competência para o efeito estava legalmente atribuída a outro órgão jurisdicional desse Estado-Membro» (sic).

Funcionando como Supremo Tribunal da União Europeia, o TJUE possui, além de outras competências específicas, a de garantir o respeito do direito na interpretação e aplicação dos tratados constitutivos (art. ${ }^{\circ}$ s $267 .^{\circ}$ a $281 .^{\circ}$ do TFUE e $19 .^{\circ}$, n. $^{\circ} 1$, do Tratado de Lisboa -TUE). Com vista a tal garantia, os Estados-Membros comprometem-se a «estabelecer as vias de recurso necessárias para assegurar uma tutela jurisdicional efetiva nos domínios abrangidos pelo direito da União» (cfr. mesmo n. ${ }^{\circ} 1$, in fine).

O TJUE (ou TJ) decide, nos termos dos tratados (cfr. o $n^{\circ} 3$ do citado art. ${ }^{\circ}$ 19..$^{\circ}$ : a) sobre os recursos interpostos por um Estado-Membro, por uma instituição ou por pessoas singulares ou coletivas; b) a título prejudicial, a pedido dos órgãos jurisdicionais nacionais, sobre a interpretação do direito da União ou sobre a validade dos atos adotados pelas instituições; c) nos demais casos previstos pelos Tratados. Em caso de dúvida, o Tribunal de Justiça decide; se, contudo, a decisão disser respeito a um membro do Tribunal Geral ou de um tribunal especializado, o Tribunal de Justiça decide após consulta (prévia) ao tribunal em causa (cfr. o art. ${ }^{\circ} 4 .^{\circ}$ do Estatuto do Tribunal de Justiça da União Europeia - ETJUE).

As diversas situações em que o TJUE pode decidir a titulo prejudicial encontram-se contempladas no art. ${ }^{\circ} 267 .^{\circ}$ do TFUE. O reenvio pode ocorrer em qualquer fase do processo, mesmo que já em fase de recurso, cabendo,

18 Cfr. o citado acórdão da RC de 13-11-2019 (2519/18).

19 Proc. 19155/16.6T8LSB.L2-6, in www.dgsi.pt/Relator. Des. MANUEL RODRIGUES. 
porém, sempre ao juiz nacional a escolha do momento azado para a submissão da questão prejudicial ao TJUE. Assim, o seu despoletamento pode ter lugar (no caso português) mesmo no seio de um recurso de revista já interposto perante o Supremo Tribunal de Justiça. Por força do disposto nessa norma, o recurso ao expediente processual do reenvio prejudicial será facultativo (o que logo inculca o termo pode) se for suscitada perante um qualquer órgão jurisdicional nacional uma qualquer questão relativa à interpretação dos tratados ou sobre a validade ou interpretação dos atos adotados pelas instituições os órgãos ou organismos da União ${ }^{20}$; já será, porém, obrigatório sempre que uma qualquer dessas questões «seja suscitada em processo pendente perante um órgão jurisdicional nacional cujas decisões não sejam suscetiveis de recurso judicial previsto no direito interno ».

Pretende-se, com esse expediente, obter, tanto quanto possível, uma uniformização interpretativa das regras de direito europeu e a sua aplicação concordante pelos vários Estados-Membros, já que a decisão do TJUE, quanto à questão prejudicial, surte força de caso julgado, assumindo, qua tale, força vinculativa perante o juiz nacional.

O reenvio prejudicial, uma vez desencadeado, representa, no fundo, uma causa (legal) atípica de suspensão da instância por ordem do tribunal (por vontade do juiz ou jussum judicis - art. $^{\circ} 269 .^{\circ}$, n..$^{\circ}$ 1, al. c), do CPC). Com efeito, a necessidade do (incidente) do reenvio surge na pendência de uma causa em curso, cabendo a sua iniciativa ou ao tribunal ou às próprias partes, mas o seu desencadeamento terá de ocorrer sempre em momento cronologicamente anterior ao da prolação da decisão final, já que o sentido decisório pode vir a ser influenciado pela posição a assumir pelo TJUE $(\mathrm{TJ})$ quanto à interpretação jurídica a fazer da norma ou do ato de direito europeu de que se trate.

Nos termos do acórdão do TJ de 9 de setembro de 2015 (C-160/14) — proferido na esteira do acórdão Köbler (C224/01, EU:C2003:513) do mesmo TJ, de 30 de setembro de 2003 -, o art. ${ }^{\circ} 267 . .^{\circ}, 3 .^{\circ} \$$, do TFUE deve ser interpretado no sentido de que um órgão jurisdicional nacional

$20 \ll \mathrm{O}$ reenvio não se torna, pois, obrigatório e automático pelo seu simples requerimento, importando antes um juízo de necessidade a efetuar pelo juiz nacional» —cfr. o acórdão da RC de 16-1-2008, CJ, n. ${ }^{\circ}$ 204, Tomo I/2008, p. 45/ Relator: Des. INÁCIO MONTEIRO. 
cujas decisões não são suscetíveis de recurso jurisdicional na ordem interna (como, entre nós, as do Supremo Tribunal de Justiça), o órgão judicial nacional (mesmo o Supremo Tribunal de Justiça) é obrigado a submeter a questão prejudicial ao TJUE. De ter presente, todavia, que, «sem prejuízo da competência atribuída ao TJUE pelos Tratados, os litígios em que a União seja parte não ficam, por esse motivo, subtraídos à competência dos órgãos jurisdicionais nacionais» ( art. $^{\circ} 274^{\circ}$ do TFUE).

«Uma ressalva deve ser feita relativamente à Carta de Direitos Fundamentais da União Europeia (CDFUE), este um instrumento dotado de força jurídica de direito primário, apenas aplicável quando a situação em apreço esteja dentro do âmbito de aplicação do DUE. Assim, quando se levantem questões relativas à violação de direitos fundamentais previstos neste instrumento, um pedido de decisão prejudicial será admissivel apenas se a alegada violação for abrangida por outra norma de direito da União. Não basta, para tal, que o órgão jurisdicional de reenvio considere que o litígio no processo principal seja abrangido pelo âmbito de aplicação do DUE, na medida em que um dos direitos em questão seja reconhecido pela Carta; torna-se ainda necessário demonstrar a existência de outro ato de direito da União para além da Carta aplicável ao considerado litígio.

7. Na atual lei processual, uma eventual decisão do TJUE tomada em sede de reenvio prejudicial, repercute-se numa causa, mesmo que já julgada em sede interna, por decisão transitada em julgado.

Com efeito, nos termos da alínea f) do art. ${ }^{\circ} 696 .^{\circ}$ do CPC, a decisão transitada em julgado «pode ser objeto de revisão» quando «seja inconciliável com decisão definitiva de uma instância internacional vinculativa para o Estado Português ». Na própria expressão legal, esta decisão-fundamento tem de provir de uma «instância internacional de recurso vinculativa para o Estado Português, visando, desde logo, e primacialmente, as decisões dimanadas do Tribunal Europeu dos Direitos do Homem (TEDH) - as quais, por força do n. ${ }^{\circ} 1$ do rtt. $^{\circ} 46 .^{\circ}$ da Convenção Europeia dos Direitos do Homem $(\mathrm{CEDH})$, obrigam todas as Partes na Convenção - e também do Tribunal 
de Justiça da União Europeia (TJUE) instituído pelos art. ${ }^{\circ}$ s $13 .^{\circ}, \mathrm{n}^{\circ} 1$ e $19 .{ }^{\circ}$ do TUE (Tratado de Lisboa) e com o respetivo estatuto (ETJUE) constante de protocolo em separado a esse Tratado.

Se, pois, uma qualquer decisão transitada em julgado, proferida por um tribunal português, colidir ou conflituar com decisão definitiva emitida por um daqueles tribunais supranacionais (desde que vinculativa para o Estado Português), é a mesma suscetível de recurso de revisão, em ordem à conformação da decisão nacional com a decisão internacional.

De destacar que, nos casos em que haja sido suscitado o expediente/incidente de reenvio prejudicial para o TJUE, em ordem a obter uma interpretação (autêntica) de uma concreta norma de direito da União, ficam adstritos à interpretação que vier a ser dada, não só o tribunal solicitante, mas também, relativamente a idêntica controvérsia, os restantes órgãos jurisdicionais portugueses (interpretação conforme e uniforme do DUE) ${ }^{21}$

A interposição de recurso de revisão com base neste fundamento deve ser efetuada em requerimento instruído com certidão da decisão da instância internacional $\left(\right.$ art. $^{\circ} 698^{\circ}$, n. ${ }^{\circ}$ 2).

O TJUE, desde o acórdão de 15 de julho de 1964, Costa v. ENEL — proferido no âmbito de um reenvio prejudicial (atual art. ${ }^{\circ} 19^{\circ}, \mathrm{n}^{\circ} 3$, alínea b), do TJUE) - e, de modo reiterado, em sucessivos acórdãos —, veio estabelecer o princípio do primado do direito europeu sobre o direito nacional, enquanto princípio estruturante do próprio ordenamento europeu. Primazia essa, de resto, expressamente consagrada na declaração $n .^{\circ} 17$ anexa à ata final da assinatura do Tratado de Lisboa e já ex-ante pelo n..$^{\circ} 4$ do art. ${ }^{\circ} 8 .^{\circ}$ da CRP, pelo que, «em caso de conflito, os tribunais nacionais devem considerar inaplicáveis as normas anteriores incompatíveis com as normas de direito da UE e devem desaplicar as normas posteriores, por violação da regra da primazia $\gg .22-23$

21 Acerca do reenvio prejudicial, cfr. F. FERREIRA DE ALMEIDA, Direito Processual Civil, vol. I, $3^{a}$ edição, Almedina, 2019, pp. 432-436.

22 Cfr. GOMES CANOTILHO/VITAL MOREIRA, Constituição da República Portuguesa Anotada, vol. I, 4.. ed., 2014, anotação XXIII ao art. ${ }^{\circ} .^{\circ}$, p. 271.

23 Sobre o primado do direito da União Europeia (DUE) sobre os ordenamentos jurídicos nacionais, sob o prisma da conformidade constitucional à luz do n. ${ }^{\circ} 4$ do art. ${ }^{\circ} .^{\circ} \mathrm{da} \mathrm{CRP}$, cfr. o acórdão do TC n. ${ }^{\circ}$ $422 / 2020$, de 15 de julho de 2020, Proc. 528/2017 e as profusas doutrina nacional e jurisprudência do TJUE no mesmo citadas. 
Os tratados, ao conformarem o sistema judicial da UE, à luz do princípio da subsidiariedade (art. ${ }^{\circ}$ 5. $^{\circ}$, n. $^{\circ}$ s 1 e 3 do TUE), não instituíram um sistema autónomo com tribunais próprios; deixando apenas reservadas ao TJUE as competências insuscetíveis de serem atribuídas aos tribunais dos Estados-Membros, convocaram estes como tribunais comuns da União. Relativamente ao ordenamento jurídico interno, no caso de Portugal, ex-vi do art. ${ }^{\circ} 204 .^{\circ}$ da CRP, no quadro de divisão de poderes, incumbe aos tribunais assegurar a prevalência ou primazia da Constituição (não interessando, no âmbito de qualquer recurso, cuidar da questão do eventual primado do direito da União, relativamente aos próprios preceitos constitucionais).

O princípio da interpretação conforme mostra-se particularmente relevante em matéria de diretivas, já que tal princípio determina que «ao aplicar o direito nacional, quer se trate de disposições anteriores ou posteriores à diretiva, o órgão jurisdicional chamado a interpretá-lo é obrigado a fazê-lo, na medida do possível, à luz do texto e da finalidade da diretiva, para atingir o resultado por ela prosseguido e cumprir desta forma o art. ${ }^{\circ} 288 .^{\circ}$ do TFUE», «desse modo se alcançando, como assinalado na doutrina, um efeito indireto, suprindo, em grau variável, a ausência de efeito direto horizontal da directiva $\gg{ }^{24-25}$.

Mas quando podem e quando devem os órgãos jurisdicionais nacionais suscitar uma questão prejudicial? E, porventura, em que fase do processo o podem fazer?

O caráter facultativo ou obrigatório de formulação de uma questão prejudicial junto do TJUE, por um órgão jurisdicional nacional, não depende do objeto da questão (interpretação dos Tratados, ou validade e interpretação dos actos adotados pelas instituições, órgãos ou organismos da União), mas sim da admissibilidade, ou não admissibilidade, de recurso ordinário da decisão a proferir pelo juiz nacional. E a formulação da questão depende da necessidade da questão prejudicial para a solução do litígio concreto. Assim, se a questão prejudicial for suscitada num processo pendente num órgão jurisdicional

24 Cfr., neste sentido, os acórdãos do TJUE, de 10 de abril de 1984, Von Colson e Kamann, 14/83 e de 26 de setembro de 1996, Arcaro, C-168/95),

25 Acerca da matéria da concorrência, cfr. J. L. CRUZ VILAÇA, O Juize a Economia -A intensidade do controlo jurisdicional em matéria de concorrência na ordem jurídica da União Europeia, in revista Julgar, Coimbra, Almedina, n. ${ }^{\circ}$ 35/2018, pp. 12-24. 
nacional cuja decisão: - admita recurso ordinário (no respetivo direito interno), o órgão jurisdicional nacional é livre de pedir ao TJUE que se pronuncie sobre ela - exceto no caso da jurisprudência Foto-Frost, isto é, no caso de o juiz nacional se inclinar para a invalidade do ato de DUE; - não admita recurso ordinário (no respetivo direito interno), então o órgão jurisdicional nacional é obrigado a submeter a questão prejudicial ao TJUE, exceto se se verificar uma das exceções à obrigatoriedade do reenvio prejudicial fixadas pela jurisprudência do TJUE.

Quanto à fase do processo em que a questão prejudicial deve ser suscitada perante o TJUE, pelo órgão jurisdicional nacional, importa, antes de mais, realçar que aquela tem de ser pertinente e útil, isto é, necessária para a decisão da causa (não tendo o TJUE poderes consultivos para responder a questóes gerais ou meramente hipotéticas). Logo, tudo aconselha (considerações de economia processual e de utilidade prática) que o reenvio prejudicial seja feito após o assentamento da factualidade relevante e uma vez resolvidas as questões de direito nacional (interno), pois só então se encontrará definido o quadro jurídico-factual em que irá atuar a interpretação ou apreciação de validade impetrada. Para o efeito, o juiz nacional deverá proferir um despacho de reenvio ${ }^{26}$.

No tocante ao eventual incumprimento, por parte de um órgão jurisdicional nacional, da obrigação de reenvio que o onerava, a violação será imputável ao Estado-Membro a que pertença. Consistindo na violação do Tratado, pode ser objeto de uma ação por incumprimento, nos termos do art. ${ }^{\circ} 258 .^{\circ}$ do TFUE e gerar responsabilidade do Estado-Juiz aferida à luz do princípio da responsabilidade dos Estados-Membros por incumprimento do DUE.

Deve, pois, o tribunal nacional recorrer ao reenvio sempre que achar necessário. De atentar em que a jurisprudência do TJUE estabeleceu, no que toca à responsabilidade do Estado, que as condições em que um Estado-Membro está obrigado a reparar os prejuízos causados a particulares por violações do direito europeu se aplicam igualmente a «danos causados pela decisão de um órgão jurisdicional nacional decidindo em última instância, que viole uma regra de direito europeu» ${ }^{27}$.

26 Cfr., acerca deste tema, LUÍSA LOURENÇO, "O Reenvio Prejudicial para o TJUE e os Pareceres Consultivos do Tribunal EFTA”, in Revista Julgar, n. ${ }^{\circ} 35$, Almedina, maio-agosto de 2018, pp. 187-202.

27 No acórdão C-224/01, Kobler, EU: 2003:513, parágrafos 25 a 55 e 59, o TJUE veio esclarecer 
8. Qual a repercussão processual da eventual preterição do poder-dever de ordenação do reenvio prejudicial quando este seja de caráter necessário?

Não - como à primeira vista possa parecer — a comissão de uma nulidade processual secundária nos termos e para os efeitos dos art. ${ }^{\circ} \mathrm{s} 195^{\circ}, \mathrm{n} .^{\circ} 1$ e $199 .^{\circ}$, por via de regra a ser conhecida sob reclamação da parte interessada nos termos e prazo cominados no $n .^{\circ} 1$ do art. $.^{\circ} 144 .^{\circ}$ e no n..$^{\circ} 1$ do art. ${ }^{\circ} 196 .^{\circ}$, todos esses preceitos do CPC. Isto pela razão de que a putativa "nulidade processual' - aparentemente traduzida na omissão de um ato ou procedimento com manifesta "influência no exame ou decisão da causa" - não se encontraria coberta pela decisão judicial que a houvesse (de modo expresso ou implícito) coonestado, pelo que a sua arguição sempre poderia (e de modo atempado) ter lugar em sede de um eventual recurso a interpor dessa decisão ${ }^{28}$. Era este o entendimento de ALBERTO DOS REIS ${ }^{29}$ e, na sua peugada, de MANUEL DE ANDRADE, ANSELMO DE CASTRO e ANTUNES VARELA, traduzido no brocardo: «dos despachos recorre-se, contra as nulidades reclama-se».

$\mathrm{Na}$ hipótese vertente, não chega a ser proferido qualquer despacho judicial autónomo sobre tal questão, mas nem por isso a decisão final que vier a proferir-se, a final (despacho, sentença ou acórdão) - sem a observância (não expressa ou tacitamente reconhecida) da solicitação do (obrigatório) reenvio — , ficará isenta de vício relevante, já que sempre será passível de arguição de nulidade por excesso de pronúncia $\left(\right.$ art. $^{\circ} 615 .^{\circ}$, n. ${ }^{\circ} 1$, al. d), in fine, $617 .^{\circ}, 666 .^{\circ}, .^{\circ} 1$, e $685 .^{\circ}$, todos do CPC). Nulidade, pois, da sentença (ou da decisão final), por nesta se haver conhecido de

que "a responsabilidade do Estado por danos causados aos particulares devido a uma violação do direito comunitário imputável a um órgão jurisdicional nacional, decidindo em última instância, podia ser efectivada no caso excepcional de esse órgão jurisdicional ter ignorado, de forma manifesta o direito aplicável", "sendo um dos critérios o não cumprimento, pelo órgão jurisdicional em causa, da sua obrigação de reenvio prejudicial» (cfr. o acórdão C-173/03, Traghetti Mediterraneo, EU:C:2006:391, parágrafos 42 a 43 .

28 Cfr., neste sentido, v. g., os acórdãos da RP de 24-9-2015, Proc. 128/14.0T8PVZ.P1 (Relatora: Des. ${ }^{a}$ JUDITE PIRES) e de 5-11-2018, Proc. 1425/17.8T8GDM.P (Relator: Des. JORGE SEABRA), e demais doutrina nos mesmos citada, ambos in www.dgsi.pt.

29 In Comentário, vol. II, p. 508. 
matéria de que não podia (prematuramente) ter-se conhecido, que não propriamente por haver sido preterido um ato processual (ou de tramitação processual) de caráter incidental ou interlocutório pelo tribunal ou o juiz que a houver proferido. E que, assim, resulta precisamente da prolação de uma decisão sem que, antes dela, se haja observado o supra-referido poder-dever do reenvio ${ }^{30}$.

9. Como atrás se deixou dito, institui a alínea f) do art. ${ }^{\circ} 696 .^{\circ}$ do CPC, como fundamento do recurso (extraordinário) de revisão, a superveniência de uma decisão transitada em julgado que seja inconciliável com decisão definitiva de uma «instância internacional de recurso vinculativa para o Estado Português». Visa essa alínea $\mathrm{f}$ ), desde logo, e primacialmente, as decisões dimanadas do Tribunal Europeu dos Direitos do Homem (TEDH) - as quais, por força do n. ${ }^{\circ} 1$ do art. ${ }^{\circ} 46 .{ }^{\circ}$, da Convenção Europeia dos Direitos do Homem (CEDH), obrigam todas as Partes na Convenção - e também do Tribunal de Justiça da União Europeia (TJUE) instituído pelos art. ${ }^{\circ}$ s $13 .^{\circ}$, n. $^{\circ} 1$ e $19 .^{\circ}$ do TUE (Tratado de Lisboa) e com o respetivo estatuto (ETJUE) constante de protocolo em separado a esse Tratado.

Entretanto, no seio do Conselho da Europa, passou a assumir especial relevo a proteção dos direitos humanos, considerada "conatural ao património definidor da identidade europeia”. Daí que o seu Estatuto estabeleça, nos art. ${ }^{\text {os }}$ $3 .^{\circ}$ e $4 .^{\circ}$, como requisito de aquisição da qualidade de Estado-Membro, que o requerente se submeta ao império do direito e assegure a qualquer individuo sob a sua jurisdição o gozo dos direitos e liberdades fundamentais inerentes à dignidade da pessoa humana. A produção normativa desenvolvida pelo Conselho da Europa veio culminar na elaboração da Convenção Europeia dos Direitos do Homem (CEDH) assinada em 1950 (respeitante a direitos civis e políticos) e da Carta Social Europeia, de 1961 (concernente a direitos económicos, sociais e culturais).

30 Cfr., em sentido idêntico e a propósito da omissão do dever de esclarecimento ou de auxílio, ou mesmo do princípio (dever) do inquisitório, M. TEIXEIRA DE SOUSA, in blog do IPPC de 16-03-2020 - Jurisprudência 2019 (196), em comentário ao acórdão da RP de 10-9-2019, Proc. 400/19.2T8AMT-D.P1 (Relatora: Des. ${ }^{a}$ FÁTIMA ANDRADE), in www.dgsi.pt. 
$\mathrm{Na} \mathrm{CEDH}$ - de que Portugal é parte signatária —, bem como nos respetivos Protocolos Adicionais, são reconhecidos diretamente ao indivíduo, e sem distinção alguma $(v \cdot g$., de sexo, raça, língua, religião, convicções pessoais, etc.), os direitos e liberdades aí consagrados, os quais se podem agrupar em seis categorias: a) proteção da integridade física; b) proteção da liberdade e tutela jurisdicional; c) proteção da intimidade pessoal e familiar; d) proteção da liberdade intelectual; e) proteção da atividade política; e f) proteção do direito de propriedade e da educação ${ }^{31}$.

A reforma do sistema de controlo instituído na $\mathrm{CEDH}$, consubstanciada no Protocolo número 11, de 11 de maio de 1994, gerou, do ponto de vista orgânico, o surgimento do novo Tribunal Europeu dos Direitos do Homem (TEDH) substitutivo do Tribunal e da Comissão anteriores, assim assumindo o sistema de controlo uma feição nitidamente judicializante. $\mathrm{O}$ novo TEDH começou a funcionar em 1 de novembro de 1998, data da entrada em vigor do Protocolo n. ${ }^{\circ}$ 11, e com sede em Estrasburgo, permitindo-se um acesso pessoal e direto ao tribunal por banda dos particulares lesados, em manifestação da personalidade jurídica internacional do individuo ${ }^{32}$.

Mas o TEDH só pode ser solicitado a conhecer de um determinado assunto ou questão depois de esgotadas todas as vias de recurso internas (princípio da exaustão dos meios internos), em conformidade com os princípios de direito internacional geralmente reconhecidos e num prazo de seis meses a contar da data da decisão interna definitiva $\left(\right.$ art. $^{\circ} 35^{\circ}, \mathrm{n} .{ }^{\circ} 1$ da mesma CEDH).

E quanto à violação da chamada delai raisonnable? O CPC reitera, no seu art. $^{\circ} 2 .^{\circ}$, o princípio constitucional da tutela jurisdicional efetiva, ao estatuir que «a proteção jurídica através dos tribunais implica o direito de obter, em prazo razoável, uma decisão judicial que aprecie, com força de caso julgado, a pretensão regularmente deduzida em juizo, bem como a possibilidade de a fazer executar $\gg\left(\mathrm{n}^{\circ} 1\right)^{33}$. No n. $^{\circ} 4$ do art. $^{\circ} 20 .^{\circ}$ do CRP, institucionaliza-se expressis verbis o direito de todos a que uma causa em que intervenham seja objeto de

31 Cfr. GONZALES CAMPOS, SÁNCHEZ RODRIGUES E SÁENZ DE SANTA MARIA, apud FRANCISCO ANTÓNIO FERREIRA DE ALMEIDA, in Direito Internacional Público, $2 .^{\circ}$ edição, Coimbra Editora, 2003 p. 342.

32 Cfr. FRANCISCO FERREIRA DE ALMEIDA, in ob. cit., pp. 342-343.

33 Acerca do conceito de prazo razoável, cfr. GOMES CANOTILHO, Direito Constitucional e Teoria da Constituição,7.a ed., p. 449. 
decisão em prazo razoável (delai raisonable) e mediante um processo equitativo (a fair trial).

Mas, se não devidamente assegurada pelo Estado-Administração a sua função de administrar celeremente a justiça e, se postergado assim o direito conferido pelo art. $^{\circ} 2 .^{\circ}, \mathrm{n} .^{\circ} 1$, do CPC, de obter, num prazo razoável, a decisão da causa, poderá a parte prejudicada reclamar indemnização pelos prejuizos sofridos (cfr. o art. ${ }^{\circ} 12 .^{\circ}$ da Lei n. ${ }^{\circ}$ 67/2007, de 31 de dezembro) ${ }^{34}{ }^{35}$. Trata-se de uma responsabilidade objetiva do Estado (no qual se integra a função jurisdicional), independente, pois, de qualquer atuação dolosa ou simplesmente negligente do juiz da causa ou dos funcionários judiciais intervenientes. Com vista a esse objetivo ressarcitório, pode ser utilizada a via do acesso pessoal e direto ao TEDH (art. ${ }^{\circ}$ s $44 .^{\circ}$ e $48 .^{\circ}$, n. $^{\circ} 1$, da CEDH) por banda dos particulares lesados para que o TEHD arbitre ao lesado, se for o caso (apreciação casuística), a reparação que julgue adequada (art. $\left.{ }^{\circ} 50 .^{\circ} \mathrm{da} \mathrm{CEDH}\right)$.

$\mathrm{O}$ recurso ao TEDH pressupõe, porém, como acima dito, a exaustão dos meios processuais internos. A ação de indemnização deve, pois, prima facie, ser endereçada aos tribunais das jurisdições nacionais e só se, esgotados nestas todos os graus de recurso, o direito à indemnização não for reconhecido, poderão as partes lesadas recorrer ao TEDH no prazo de seis meses a contar da data da decisão interna definitiva $\left(\right.$ art $^{\circ} 35^{\circ}, \mathrm{n} .^{\circ} 1$, da mesma CEDH).

\footnotetext{
34 Sobre o direito à obtenção de uma decisão em prazo razoável, vide JOAQUIM LOUREIRO, Convenção Europeia dos Direitos do Homem: Queixas contra o Estado Português, in Scientia Juridica, n. ${ }^{\text {os }} 259 / 261$, jan/jul. de 1996, pp. 73 e ss.. Uma lei processual pouco adequada à eficiência da justiça ou o mau estado da organização judiciária não afastam a violação da CEDH — cfr. VELU-ERGEC, La Convention Européenne dês Droits de L,Homme, Bruxelles, Bruylant, 1990, pp. 55 e 447.

35 Acerca dos pressupostos da responsabilidade civil extracontratual do Estado pelo atraso na administração da justiça da consequente obrigação de indemnizar, designadamente por violação da obrigação de garantir o direito constitucional a uma decisão em prazo razoável, (violação da délai raisonnable), cfr., $v . g$., o acórdão do STA de 13-3-2109, Proc. 0437/12.2BEALM 0683/18, in www. dgsi.pt/Cons. ${ }^{a}$ TERESA DE SOUSA. E, designadamente, sobre a prova do nexo causal entre o facto e o dano invocado pelo lesado, - cfr. o acórdão do STA de 17-1-2007, in ADSTA, n ${ }^{\circ}$ 547, pp. 1217 e ss./Cons. ${ }^{\circ}$ JORGE DE SOUSA e demais jurisprudência nesse aresto mencionada. Cfr., também, incindindo sobre esta temática, os acórdão do STA de 8-3-2018, Proc. 0350/17 (Relatora: Cons. ${ }^{2}$ ANA PAULA PORTELA), de 5-3-2020, Proc. 4/17.5BELSB (Relator: Cons. ${ }^{\circ}$ FONSECA DA PAZ) e de 23-4-2020, Proc. 0290/13.9BESNT, (Relatora: Cons. ${ }^{a}$ MARIA BENEDITA URBANO), todos in www.dgsi.pt..
} 
10. Um outro (novo) fundamento para o recurso extraordinário de revisão foi (como atrás já referido) introduzido pelo art. ${ }^{\circ} 3 .^{\circ}$ da Lei no 117/2019, de 13 de setembro, entrada em vigor em 1 de janeiro de 2020. Nos termos da novel al. h) do art. ${ }^{\circ} 696 .^{\circ}$ do CPC, «a decisão transitada pode ser objeto de revisão sempre que seja suscetivel de originar responsabilidade civil do Estado por danos emergentes da função jurisdicional, verificando-se o disposto no art. ${ }^{\circ} 696 .^{\circ}-\mathrm{A} \gg$.

Nos termos do n. $^{\circ} 1$ deste último preceito, a revisão com este fundamento típico só é admissível se o recorrente: a) não tiver contribuido, por ação ou omissão, para o vício imputado à decisão; b) tiver esgotado todos os meios de impugnação da decisão quanto à matéria suscetivel de originar a responsabilidade civil do Estado (princípio da exaustão dos meios legais impugnatórios de reação). Recurso que, pela sua natureza, deve (obrigatoriamente) ser também interposto contra o Estado (art. ${ }^{\circ} 696 .^{\circ}-\mathrm{A}, \mathrm{n} .^{\circ}$ 2).

Ficou, deste modo, suprida a supra-apontada lacuna da falta de regime processual específico para exercitação da responsabilidade civil do Estado pelo exercício da função jurisdicional. Não mais se torna agora pertinente a anterior dualidade de regimes quanto à necessidade ou à dispensa da revogação prévia da decisão incursa em erro judiciário: a revogação prévia da decisão pode (deve) ser sempre obtida através do recurso extraordinário de revisão, qualquer que seja o fundamento da alegada responsabilidade civil do Estado (cfr. art. ${ }^{\circ} 701 .^{\circ}$, n. ${ }^{\circ} 1$, do CPC).

Este novo fundamento para o recurso de revisão arreda a possibilidade de os acórdãos das Relações ou do STJ serem (em 1. ${ }^{\circ}$ grau) sindicados, em sede de responsabilidade civil do Estado, nos tribunais de 1. instância, permitindo, contudo, a dedução do pedido de indemnização contra o Estado no juizo rescisório do recurso de revisão.

De abrir aqui um parêntesis sobre a natureza jurídica do recurso de revisão.

Perfilhamos, na esteira de ALBERTO DOS REIS E ${ }^{36}$ e de AMÂNCIO FERREIRA $^{37}$, a tese de que a revisão assume figura procesual hibrida: um misto

36 In Código de Processo Civil Anotado, vol. VI cit., p. 376.

37 Cfr. Manual cit., p. 343. 
de recurso e de ação. A fase rescindente, assemelha-se a um recurso e à qual se aplicam algumas das disposições gerais sobre recursos ( $v . g$., o disposto nos art. ${ }^{\circ} \mathrm{S} 631 .^{\circ}, 632 .^{\circ}$ e $637,^{\circ}, \mathrm{n} .^{\circ} 1$ ). Se o recurso for admitido (na fase rescindente) proceder-se-á à sua instrução, seguindo-se a tramitação própria do processo comum declarativo ( $\operatorname{art}^{\circ}{ }^{\circ} 700 .^{\circ}, \mathrm{n}^{\circ}$ 2). Se julgado procedente o pedido de revisão (por haver vingado o fundamento legal invocado) reabre-se (renasce) a relação processual a desenvolver nas instâncias $\left(1 .^{\mathrm{a}}\right.$ ou $2 .^{\mathrm{a}}$ ) ou no Supremo, conforme o tribunal em que penda o processo de revisão, até se adregar uma nova decisão de mérito, que tanto pode ser de idêntico sentido ao da decisão revidenda como de sentido diferente. O juizo rescisório tem como finalidade a realização de uma nova instrução, discussão e julgamento da causa, ou, tão-somente, uma reapreciação desta, consoante o motivo conducente à emissão do juízo rescindente.

De salientar que o (novo) regime é totalmente compativel com a jurisprudência europeia, dado que esta apenas determinava a impossibilidade da exigência da revogação prévia da decisão violadora de direito europeu quando, em termos práticos, aquela revogação não estivesse legalmente assegurada; agora, conforme o novo regime, passa a ser viável a revogação prévia da decisão, independentemente de a violação imputada pelo recorrente à decisão respeitar ao direito europeu ou ao direito interno. $\mathrm{O}$ novo regime acaba, pois, com qualquer distinção entre decisões (supostamente) violadoras do direito europeu e decisões (alegadamente) violadoras do direito interno ${ }^{38}$.

Traduções práticas do novo regime legal (processual) são:

a) a decisão transitada em julgado pode ser objeto de revisão quando suscetivel de originar a responsabilidade civil do Estado por danos emergentes do exercício da função jurisdicional ( art. $^{\circ}$ 696. ${ }^{\circ}$, alínea h)), desde que tal responsabilidade decorra de decisões jurisdicionais manifestamente inconstitucionais ou ilegais ou injustificadas por erro grosseiro na apreciação dos respetivos pressupostos de facto (art. ${ }^{\circ} 13 .^{\circ}$, n. $^{\circ} 1$, do RJRCEE);

b) a revisão só é admissivel se o recorrente não tiver contribuido, por ação ou omissão, para o vício que imputa à decisão (art. ${ }^{\circ}$ 696.․-A, n. ${ }^{\circ}$ 1, al. a), do CPC); quer dizer: o recorrente que invoque a errónea ou viciada aplicação do regime legal, e

38 Cfr., acerca deste tema, M. TEIXEIRA DE SOUSA/CARLOS LOPES DO REGO/ ANTÓNIO ABRANTES GERALDES/PEDRO PINHEIRO TORRES, O Novo Regime do Processo de Inventário e Outras Alterações na Legislação Processual Civil, Almedina, 2020, pp. 221-223. 
que, no decurso do processo, nunca se haja oposto à aplicação desse regime, ou que nunca haja manifestado qualquer discordância quanto à concreta apreciação e/ou assentamento da matéria de facto pelo tribunal, não poderá interpor recurso de revisão contra a sentença; isto pela simples razão de que, nestas circunstâncias, o mesmo não pode ser considerado vencido e, por isso, não possui, para tal, a competente legitimidade (cfr. o art. $^{\circ} 631 .^{\circ}$, n. $^{\circ} 1$, do CPC);

c) a revisão só é admissivel se o recorrente tiver esgotado (exaurido) todos os meios de impugnação da decisão quanto à matéria suscetível de originar a responsabilidade civil do Estado ( art. $^{\circ}$ 696. ${ }^{\circ}$-A, n..$^{\circ}$ 1, al. b)); pelo que, se o recorrente não tiver reclamado ou recorrido da decisão ora pretendida impugnar, essa sua inércia processual surte eficácia preclusiva da admissibilidade do recurso de revisão;

d) o recurso de revisão deve ser interposto não só contra a contraparte, mas também contra o Estado em litisconsórcio necessário passivo (art. ${ }^{\circ}$ 696.-A, n. ${ }^{\circ} 2$ ); obrigatoriedade que decorre, logicamente, da circunstância de o recurso ter por fundamento e objeto a eventual responsabilidade civil do Estado pelo exercício da função jurisdicional;

e) o recurso é interposto desde que a decisão em que se funda a revisão se haja tornado definitiva ou haja transitado em julgado (art. ${ }^{\circ} 697 .^{\circ}, \mathrm{n} .{ }^{\circ} 2$, al. b)).

Ao invés de qualquer recurso ordinário, cuja finalidade é a de obstar ao trânsito em julgado de uma decisão desfavorável, com o recurso extraordinário de revisão visa-se (em última ratio) corrigir os erros de julgamento de que enferme uma decisão judicial já transitada em julgado (insuscetível, pois, de impugnação pela via ordinária contenciosa) ${ }^{39}$.

Ao contrário do que sucede com os recursos ordinários, o recurso de revisão não se encontra condicionado pelo valor da alçada. Isto porque qualquer dos respetivos vícios-fundamento assume um tal grau de gravidade, em termos de violação drástica do princípio da justiça, que seria incompreensível que o escasso valor da causa fosse obstativo da sua impugnação extraordinária ${ }^{40}$.

O expediente ou remédio processual da revisão visa a substituição da decisão revidenda por outra não inquinada dos vícios subjacentes à sua impugnação

39 Cfr., quanto a este ponto, F. FERREIRA DE ALMEIDA, Direito Processual Civil, vol. II, 2. ${ }^{2}$ edição, Coimbra, Almedina, 2019, pp. 646-647.

40 Cfr. SANTOS SILVEIRA, Impugnação das Decisões em Processo Civil, 1970, p. 457. 
ou anulação. No fundo, uma erupção de uma certa relatividade do principio da autoridade ou da força do caso julgado, traduzida na prevalência das «exigências da justiça, face à necessidade da segurança e da certeza jurídicas imanentes a uma decisão judicial dotada da firmeza, força e autoridade advinda do respetivo trânsito em julgado $\gg^{41}$.

O recurso de revisão é interposto no tribunal que proferiu a decisão a rever, seja ele o tribunal de $1^{a}$ instância, a Relação ou o Supremo (art. ${ }^{\circ} 697 .^{\circ}$, n. ${ }^{\circ}$ ). Se correr perante um tribunal superior, o respetivo relator exercerá, até ao julgamento, todas as funções que competem, em primeira instância, ao juiz de direito, com a possibilidade de reclamação para a conferência (art. ${ }^{\circ}$ 701. $\left.{ }^{\circ}-\mathrm{A}, \mathrm{n} .{ }^{\circ} 2\right)^{42}$.

Se a decisão (alegadamente lesiva) impugnada vier a ser revogada em sede da fase rescindente do recurso de revisão, passar-se-á à fase rescisória do mesmo recurso, a qual deverá conter as seguintes especialidades: - o recorrente deve ser notificado para, no prazo de 30 dias, formular o pedido de indemnização contra o Estado (art. ${ }^{\circ} 701 .^{\circ}$, n. $^{\circ} 1$, al. e), do CPC); isto porque, verificado que a decisão padece (realmente) de erro judiciário, ficará assente que o Estado é civilmente responsável perante o lesado/recorrente, devendo, pois, a este ser facultada a oportunidade de deduzir o seu pedido (quantificado) de indemnização.

Exercido que seja o respetivo contraditório (no prazo de 30 dias a contar da notificação do pedido indemnizatório), o processo prosseguirá, com uma tramitação a definir pelo relator com base nos poderes de gestão processual (art. ${ }^{\circ} 6 .^{\circ}$, n. $^{\circ}$ ) e de adequação formal (art. ${ }^{\circ} 547 .^{\circ}$ ), ambos os preceitos do CPC, para o apuramento da indemnização devida pelo Estado ao recorrente (art. ${ }^{\circ} 7010^{\circ}-\mathrm{A}, \mathrm{n} .^{\circ} 1$ ). A opção pela possibilidade de exercitação desses poderes processuais pelo juiz (em detrimento de uma definição legal da tramitação) deve, contudo, ser apenas tomada após o Estado haver exercido (previamente) o contraditório quanto ao pedido indemnização.

De notar que as decisões proferidas no termo ou na pendência da fase rescisória (sendo nesta aplicáveis as fases do processo comum de declaração), são

41 Cfr. ALBERTO DOS REIS, Código de Processo Civil Anotado, vol. VI cit., pp. 336-337.

42 Acerca do tribunal competente para a tramitação do recurso extraordinário de revisão, cfr. $\mathrm{F}$. FERREIRA DE ALMEIDA, Direito Processual Civil, vol. II, 2. ${ }^{a}$ edição cit., pp. 665-666. 
passíveis de recurso ordinário, em perfeita similitude com as decisões proferidas na ação em que foi proferida a sentença revidenda, com atenção, pois, aos valores da alçada e da sucumbência ( art. $^{\circ} 697 . .^{\circ}$, n. ${ }^{\circ}$ 6).

E, nada dizendo a lei em contrário, a sentença substitutiva (da que foi rescindida) poderá igualmente ser objeto de um novo recurso de revisão (revisio/revisionais) com base em qualquer dos vícios a que se reportam as alíneas a) a g) do art. ${ }^{\circ} 696 \cdot^{\circ 43}$.

43 Cfr., neste sentido, ALBERTO DOS REIS, Código de Processo Civil Anotado, vol. V, cit., pp. 403 e ss.. 
